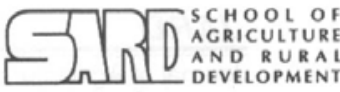
কৃষि ও পল্লী উक्षয়न অনুষদ
Available online at http:/ / www.banglajol.info/index.php/jard
J ARD

Journal of Agriculture \& Rural Development

\title{
Effect of Boron for Correcting the Deformed Shape and Size of Jackfruit
}

\author{
N. K. HALDER ${ }^{* 1}$, A. T. M. FARID ${ }^{2}$ \& M. A. SIDDIKY ${ }^{2}$ \\ ${ }^{1}$ Horticulture Research Centre, Bangladesh Agricultural Research Institute, Gazipur-1701, Bangladesh \\ ${ }^{2}$ Soil Science Division, Bangladesh Agricultural Research Institute, Gazipur-1701, Bangladesh
}

\begin{abstract}
A field study on jackfruit (cv. local) was conducted at Brown Hill Soils (Eutrochrepts) of South Eastern Hilly regions (AEZ/29) under Hill Tracts Agricultural Research Station, Ramgarh, Khagrachri during the years of 2002-2003 and 2003-2004. The objective was to reduce the number of deformed fruits through boron fertilization and to obtain increased number of normal fruits/tree. Four levels of boron $\left(0,5,10\right.$ and $15 \mathrm{~g}$ tree $\left.{ }^{-1}\right)$ and three age groups $(10,15$ and 20 years) of jackfruit trees were considered in the study. The effect of boron application on plant of different age groups was found highly significant on flower and fruit characters of jackfruit. However, the highest level of boron applied (15 g tree $\left.{ }^{-1}\right)$ to the highest age group of plants (20 years) produced significant number of normal fruits (78 and 140 tree $^{-1}$ ) and reduced the number of deformed fruits per tree in two consecutive cropping years 2002-2003 and 2003-2004, respectively. The highest mean normal fruits (111/tree) and lowest percent of deformed fruits (24\%) were recorded due to application of highest level of $B\left(15 \mathrm{~g}\right.$ tree $\left.{ }^{-1}\right)$. The significant increasing in female flowers and male to female ratio contributed towards the increased number of normal fruits having more fruit weight and normal size.
\end{abstract}

Key words: Jackfruit, boron, fertilization, deformed fruits.

\section{INTRODUCTION}

Jackfruit (Artocarpus heterophillus L.) is a very popular summer fruit in Bangladesh. Its position is next to mango and banana in acreage (66110 acres) and production (267495 Mt, BBS, 2000). Tender fruits appear in the market in spring and continue till summer as a popular vegetable. Ripe fruit has high nutritive value. The fruits contain minerals, vitamin A and C (Hossain and Haque, 1977). It plays an important role in meeting nutritional requirement for the peoples of Bangladesh. The jackfruit is grown on a wide variety of soil, although, it prefers a rich deep alluvial soil. Soil drainage is of utmost importance. It can also be grown on open-textured high soil or laterite soil. It also flourishes in humid hill slopes up to an elevation of $1500 \mathrm{~m}$ (Hayes, 1957). In Chittagong hill tract region the hilly people grow this fruit abundantly but they do not get real value for shriveled shape and size. The consumers generally do not like to purchase deformed shape fruits for which the growers feel discouraged. The dropping of female spikes and irregular shaped fruits are cardinal problems in jackfruit production in Bangladesh. One of the reason might be that the female spikes generally appear on the trunk and main branches. On

* Corresponding author: Senior Scientific Officer, Horticulture Research Centre, BARI, Gazipur-1701, Tel: 02-91261497, E-mail: nirmalhrc@yahoo.com

(C) 2008 School of Agriculture and Rural Development, Bangladesh Open University, All rights reserved. 
the other hand, the male spikes appear in the periphery. Their anthesis period is not also synchronized. So, there is a possibility of improper pollination. If the flowers on all the sides are not pollinated, the fruit does not develop normally as a result the size and shape may be small and irregular. Lack of pollination may also lead to the droping of the female spikes (Samaddar and Yadav, 1982; Jessy et al., 1996a). The number of fruits per tree is dependent on the number of female spikes and the ratio of male to female spikes (Sankar and Singh, 1965; Jessy et al., 1996b). The final size attained and the shape of the fruit depends on the number of flowers pollinated and fertilized and the pattern of pollination of flowers. Unfertilized flowers also lead to irregular shape of the fruits (Sharma, 1964). It has been found that B deficiency restricts the germination of pollen grains. Imbalanced fertilization sometimes causes to enhance depollination. If pollination and fertilization fail to occur within 3-6 days after anthesis, the fruits become twisted and shriveled in shape (Bose, 1990). Boron may stimulate the normal flow of hormone and enhance pollen grain and pollen tube formation. It also increases the stickiness of the stigma for receiving the pollen grains. However, till now work related to deformed shape of jackfruit in Bangladesh is very limited and sporadic. Therefore, an experiment was undertaken to find out the optimum dose of boron for correcting the deformed shape and size of jackfruit.

\section{MATERIALS AND METHODS}

The experiment was conducted at Agricultural Research Station, Ramgarh, Kharachari during the periods of July to June of 2002-2003 and 2003-2004. The experimental soil was sandy clay loam. The physical and chemical properties of the soil of the experimental site have been presented in Table 1. The analyzed soil of the experimental site is sandy clay loom and the $\mathrm{pH}$ indicates the soil is strongly acidic in nature. The fertility status of the soil is very poor as the organic matter content and other nutrient elements were found to be below the critical level. The experiment was designed in randomized block with three replications. The plot dimension and spacing were adjusted in the established orchard of the station. The trees were mainly selected near the top of the hill nearing $40 \mathrm{~m}$ above the sea level. Local cultivars of jackfruit were selected as test crop. Each and every tree was considered as a treatment under the replications. There were four levels of boron viz. 0,5,10, and $15 \mathrm{~g} \mathrm{tree}^{-1}$ and three age group of 10,15 and 20 years were considered in the study. The combined blanket dose @ $920 \mathrm{~g} \mathrm{~N}: 200 \mathrm{~g} \mathrm{P} 250 \mathrm{~g} \mathrm{~K}: 85 \mathrm{~g} \mathrm{~S}$ tree ${ }^{1}$ and $10 \mathrm{~kg}$ cowdung were used in the experiment. Thirty six plants of twelve (12) from every group were randomly selected for the study. After harvesting of fruits light pruning was done in selected trees prior to fertilization. Fertilizer application was done to the soil of the orchard in two equal splits in last week of July and mid November by ring placement method. Intercultural operations were also performed in time. Data on time of flower initiation, number of female spikes, number of male spikes and number of fruit set per plant were recorded in time. Ripe jackfruits were harvested from April to June 2003 and 2004, respectively. Ten fruits of different size and shape were randomly selected from every treatment for data collection. All the necessary data on different parameters were compiled for statistical analysis and adjudged with least significant difference (LSD) at $5 \%$ level of significance.

Table 1a. Physical and chemical properties of experimental soils prior to fertilization at Hill Tracts Agricultural Research Station, Ramgarh (2002-2003)

\begin{tabular}{|c|c|c|c|c|c|c|c|c|c|c|c|c|c|}
\hline \multirow{2}{*}{ Texture } & \multirow{2}{*}{$\mathrm{pH}$} & \multirow{2}{*}{$\begin{array}{l}\text { OM } \\
\%\end{array}$} & \multicolumn{3}{|c|}{$\mathrm{meq} / 100 \mathrm{gm}$} & \multirow{2}{*}{$\begin{array}{l}\text { Total } \\
\mathrm{N} \%\end{array}$} & \multicolumn{7}{|c|}{$\mu \mathrm{g} \mathrm{g}^{-1}$} \\
\hline & & & $\mathrm{Ca}$ & $\mathrm{Mg}$ & $\mathrm{K}$ & & $\mathrm{P}$ & $\mathrm{S}$ & B & $\mathrm{Cu}$ & $\mathrm{Fe}$ & $\mathrm{Mn}$ & $\mathrm{Zn}$ \\
\hline $\begin{array}{l}\text { Sandy Clay } \\
\text { Loam }\end{array}$ & 4.5 & 1.04 & 1.1 & 0.4 & 0.1 & 0.055 & 3.6 & 15 & 0.22 & 4.0 & 165 & 17.7 & 1.0 \\
\hline Critical level & - & - & 2.0 & 0.8 & 0.2 & - & 14.0 & 14 & 0.2 & 1.0 & 10.0 & 5.0 & 2.0 \\
\hline
\end{tabular}


Table 1b. Physical and chemical properties of experimental soils prior to fertilization at Hill Tracts Agricultural Research Station, Ramgarh (2003-2004)

\begin{tabular}{|c|c|c|c|c|c|c|c|c|c|c|c|c|c|}
\hline \multirow{2}{*}{ Texture } & \multirow{2}{*}{$\mathrm{pH}$} & \multirow{2}{*}{$\begin{array}{c}\mathrm{OM} \\
\%\end{array}$} & \multirow{2}{*}{$\begin{array}{c}\text { Total N } \\
\%\end{array}$} & \multicolumn{3}{|c|}{$\mathrm{meq} / 100 \mathrm{gm}$} & \multicolumn{7}{|c|}{$\mu \mathrm{g} \mathrm{g}^{-1}$} \\
\hline & & & & $\mathrm{Ca}$ & $\mathrm{Mg}$ & $\mathrm{K}$ & $\mathrm{P}$ & $\mathrm{S}$ & $\mathrm{B}$ & $\mathrm{Cu}$ & $\mathrm{Fe}$ & $\mathrm{Mn}$ & $\mathrm{Zn}$ \\
\hline \multirow{2}{*}{ Sandy clay } & 4.9 & 1.21 & 0.066 & 3.8 & 1.7 & 0.11 & 7 & 12 & 0.28 & 4 & 225 & 13 & 3.4 \\
\hline & $\mathrm{S}^{*}$ & low & very low & medium & medium & very low & very low & very low & low & High & very low & medium & medium \\
\hline Critical level & - & - & 0.12 & 2.0 & 0.8 & 0.2 & 14.0 & 14 & 0.2 & 1.0 & 10.0 & 5.0 & 2.0 \\
\hline
\end{tabular}

$\mathrm{S}^{*}=$ Strongly acidic

Source: Soil Science Laboratory, BARI.

\section{RESULTS AND DISCUSSION}

\section{Integrated effect of boron and age of trees}

Flower and fruit characters of jackfruit significantly responded to the combined effects of boron and age of tree in both the years (Tables $2 \mathrm{a}$ and $2 \mathrm{~b}$ ). Result shows that increase in female flower, fruit number, weight and size of fruits and drastic reduction of deformed shape fruits per tree significantly influenced by interaction effect of boron and age of tree. It is clearly noticed that as the increase of boron level along with age group profusely increased the flower and fruit characters and significantly contributed to the reduction of deformed shape of fruits. It indicates that the increase of female flowers and proportionate increase of male to female spike ratio might have produced increased number of normal fruits and simultaneous lowering of deformed fruits/tree. The study also revealed that all the selected parameters were highly responded to the different boron levels up to @ $15 \mathrm{~g} \mathrm{~B}$ tree ${ }^{-1}$ in the $2^{\text {nd }}$ year compared to $1^{\text {st }}$ year result. It might be the reason of proper assimilation and utilization of boron by feeding roots of trees. It is also found from Tables $2 a$ and $2 b$ that number of female spikes increased with highest boron level @ $15 \mathrm{~g} \mathrm{~B}^{\text {tree }}{ }^{-1}$ along with 20 year old trees. In both the years, the highest number of female spikes (141 and 157), normal fruits (78 and 140), maximum fruit weight $(8.20 \mathrm{~kg}$ and $11.00 \mathrm{~kg})$ and significantly reduced number of deformed shape fruits were recorded in the same treatment. The male to female ratio proportionately narrowed with the increase of boron level up to $15 \mathrm{~g} \mathrm{~B}$ tree ${ }^{-1}$. The balanced fertilization with the inclusion of boron might have stimulated the normal flow of hormone and enhanced pollen grain and pollen tube formation which contributed to the increase of number of female spikes, ratio of male to female spikes and normal shaped fruits/tree. A negative relationship between boron and deformed fruits and linear relationship of boron and female spikes/tree have been presented in Fig. $a$ and b.

Table 2a. Interaction effect of boron and age of trees on the yield and yield contributing characters of Jackfruit during 2002-2003 at Hill Tract Agricultural Research Station, Ramgarh, Khagrachari

\begin{tabular}{|c|c|c|c|c|c|c|c|c|c|c|c|}
\hline \multirow{2}{*}{$\begin{array}{l}\text { Age of } \\
\text { tree }\end{array}$} & \multirow{2}{*}{$\begin{array}{c}\text { Boron } \\
\text { level g } \\
\text { tree }^{-1}\end{array}$} & \multirow{2}{*}{$\begin{array}{c}\text { Male } \\
\text { spikes } \\
\text { tree }^{-1}\end{array}$} & \multirow{2}{*}{$\begin{array}{c}\text { Female } \\
\text { spikes } \\
\text { tree }^{-1}\end{array}$} & \multirow{2}{*}{$\begin{array}{l}\text { Male: } \\
\text { Female }\end{array}$} & \multirow{2}{*}{$\begin{array}{l}\text { Total } \\
\text { fruits } \\
\text { tree }^{-1}\end{array}$} & \multirow{2}{*}{$\begin{array}{c}\text { Normal } \\
\text { fruits } \\
\text { tree }^{-1}\end{array}$} & \multirow{2}{*}{$\begin{array}{c}\text { Deformed } \\
\text { Fruits } \\
\text { tree }^{-1}\end{array}$} & \multirow{2}{*}{$\begin{array}{c}\% \\
\text { Deformed } \\
\text { Fruits }\end{array}$} & \multirow{2}{*}{$\begin{array}{c}\text { Individual } \\
\text { fruit } \\
\text { wt.(kg) }\end{array}$} & \multicolumn{2}{|c|}{ Fruit size } \\
\hline & & & & & & & & & & $\begin{array}{l}\text { Length } \\
(\mathrm{cm})\end{array}$ & $\begin{array}{c}\text { Circumference } \\
(\mathrm{cm})\end{array}$ \\
\hline \multirow{4}{*}{10} & 0 & 87 & 24 & $3.6: 1$ & 15 & 2 & 13 & 87 & 3.50 & 23 & 36 \\
\hline & 5 & 72 & 39 & 1.9:1 & 31 & 9 & 21 & 68 & 5.50 & 23 & 50 \\
\hline & 10 & 80 & 67 & $1.2: 1$ & 61 & 32 & 29 & 48 & 5.10 & 26 & 51 \\
\hline & 15 & 105 & 90 & $1.2: 1$ & 85 & 37 & 48 & 56 & 6.60 & 27 & 53 \\
\hline \multirow{4}{*}{15} & 0 & 62 & 22 & 2.8:1 & 16 & 4 & 12 & 75 & 4.10 & 21 & 59 \\
\hline & 5 & 44 & 35 & 1.3:1 & 33 & 14 & 19 & 58 & 7.00 & 28 & 62 \\
\hline & 10 & 45 & 27 & $1.7: 1$ & 23 & 8 & 15 & 65 & 5.20 & 25 & 58 \\
\hline & 15 & 79 & 128 & $0.6: 1$ & 126 & 61 & 65 & 52 & 7.60 & 31 & 65 \\
\hline \multirow{4}{*}{20} & 0 & 72 & 43 & $1.7: 1$ & 36 & 13 & 23 & 64 & 4.10 & 25 & 43 \\
\hline & 5 & 99 & 46 & $2.2: 1$ & 42 & 17 & 25 & 60 & 6.20 & 33 & 45 \\
\hline & 10 & 135 & 104 & 1.3:1 & 102 & 59 & 43 & 42 & 7.70 & 34 & 68 \\
\hline & 15 & 93 & 141 & $0.7: 1$ & 139 & 78 & 61 & 44 & 8.20 & 37 & 70 \\
\hline \multicolumn{2}{|c|}{ LSD (0.05) } & NS & 9.5 & - & 10.6 & 8.8 & 6.0 & 1.8 & - & 3.4 & 8.8 \\
\hline CV \% & 6.7 & 14.4 & 8.8 & - & 11.0 & 18.6 & 11.5 & - & 18.3 & 7.1 & 9.40 \\
\hline
\end{tabular}

NS $=$ Not significant 
N. K. Halder et al.

Table 2b. Interaction effect of boron and age of trees on the yield and yield contributing characters of Jackfruit during 2003-2004 at Agricultural Research Station, Ramgarh, Khagrachari

\begin{tabular}{|c|c|c|c|c|c|c|c|c|c|c|c|}
\hline \multirow{2}{*}{$\begin{array}{c}\text { Age of } \\
\text { tree }\end{array}$} & \multirow{2}{*}{$\begin{array}{l}\text { Boron } \\
\text { level g } \\
\text { tree }^{-1}\end{array}$} & \multirow{2}{*}{$\begin{array}{l}\text { Male } \\
\text { spikes } \\
\text { trees }^{-1}\end{array}$} & \multirow{2}{*}{$\begin{array}{c}\text { Female } \\
\text { spikes }^{-1} \\
\text { tree }^{-1}\end{array}$} & \multirow{2}{*}{$\begin{array}{l}\text { Male: } \\
\text { Female }\end{array}$} & \multirow{2}{*}{$\begin{array}{l}\text { Total } \\
\text { fruits } \\
\text { tree }{ }^{-1}\end{array}$} & \multirow{2}{*}{$\begin{array}{l}\text { Normal } \\
\text { fruits } \\
\text { tree }^{-1}\end{array}$} & \multirow{2}{*}{$\begin{array}{l}\text { Deformed } \\
\text { fruits } \\
\text { tree }^{-1}\end{array}$} & \multirow{2}{*}{$\begin{array}{c}\% \\
\text { Deformed } \\
\text { Fruits }\end{array}$} & \multirow{2}{*}{$\begin{array}{l}\text { Individual } \\
\text { fruit wt. } \\
(\mathrm{kg})\end{array}$} & \multicolumn{2}{|c|}{ Fruit size } \\
\hline & & & & & & & & & & $\begin{array}{l}\text { Length } \\
(\mathrm{cm})\end{array}$ & $\begin{array}{l}\text { Circumference } \\
(\mathrm{cm})\end{array}$ \\
\hline \multirow{4}{*}{10} & 0 & 85 & 21 & $4.0: 1$ & 19 & 8 & 11 & 58 & 3.0 & 24 & 36 \\
\hline & 90 & 90 & 54 & $1.7: 1$ & 52 & 40 & 12 & 23 & 6.0 & 25 & 38 \\
\hline & 10 & 110 & 67 & $1.6: 1$ & 63 & 52 & 11 & 17 & 6.37 & 28 & 41 \\
\hline & 15 & 116 & 88 & $1.4: 1$ & 85 & 72 & 13 & 15 & 7.10 & 29 & 50 \\
\hline \multirow{4}{*}{15} & 0 & 99 & 26 & $3.8: 1$ & 24 & 6 & 18 & 75 & 3.90 & 26 & 55 \\
\hline & 90 & 116 & 60 & $1.9: 1$ & 57 & 45 & 12 & 21 & 6.30 & 27 & 60 \\
\hline & 10 & 150 & 73 & 2.1:1 & 71 & 60 & 11 & 15 & 7.11 & 30 & 64 \\
\hline & 15 & 185 & 137 & 1.4:1 & 134 & 122 & 12 & 09 & 8.23 & 32 & 70 \\
\hline \multirow{4}{*}{20} & 0 & 84 & 37 & 2.3:1 & 35 & 7 & 28 & 80 & 4.73 & 26 & 60 \\
\hline & 90 & 109 & 67 & $1.7: 1$ & 65 & 54 & 11 & 17 & 8.23 & 29 & 63 \\
\hline & 10 & 142 & 143 & $1.0: 1$ & 140 & 124 & 13 & 09 & 9.47 & 37 & 70 \\
\hline & 15 & 166 & 157 & $1.1: 1$ & 154 & 140 & 14 & 09 & 11.00 & 44 & 80 \\
\hline \multicolumn{2}{|c|}{ LSD (0.05) } & 5.83 & 5.56 & - & 4.97 & 8.95 & 4.2 & - & 0.42 & 0.77 & 2.05 \\
\hline \multicolumn{2}{|c|}{ CV \% } & 9.80 & 4.28 & - & 4.90 & 8.7 & 7.8 & - & 3.70 & 5.5 & 3.50 \\
\hline
\end{tabular}

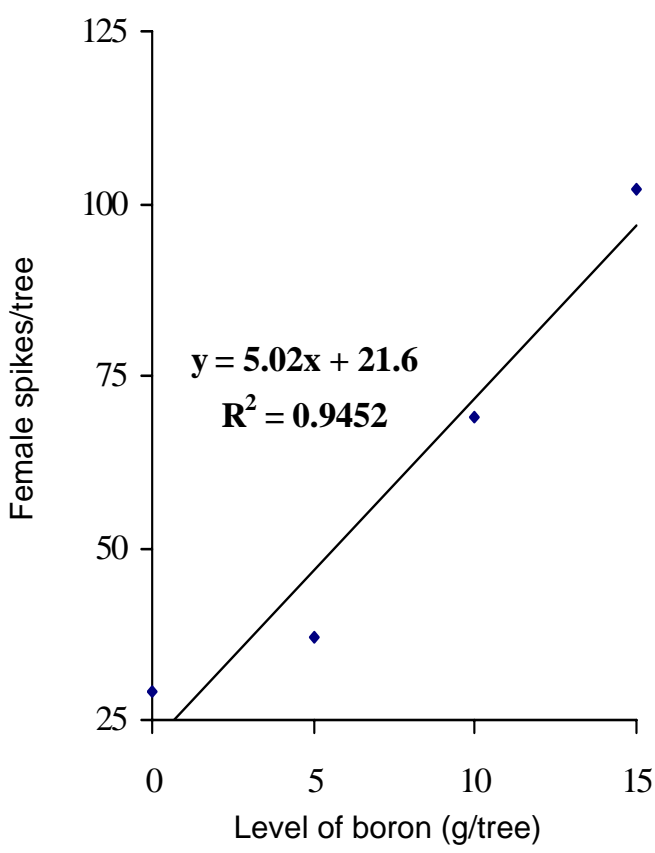

Fig. a. Response of boron to no. of female spikes/tree

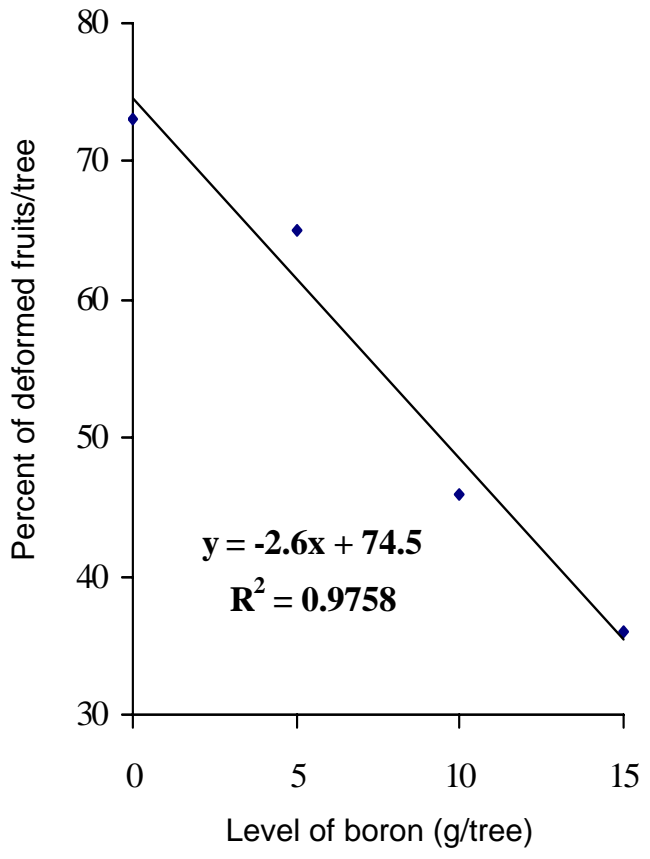

Fig. a. Response of boron to percent of deformed fruits/tree 


\section{Effect of boron}

The mean effect of boron on the yield and other yield contributing characters of different age group of the trees have been shown in table $3 a$ and $3 b$. The number of male and female spikes, total fruits, normal fruits, fruit weight and size were significantly increased by the increase of boron levels from 0 $15 \mathrm{~g} \mathrm{tree}^{-1}$. It is noticeable from Tables $3 \mathrm{a}$ and $3 \mathrm{~b}$ that all the fruit and flower characters were sharply increased in $2^{\text {nd }}$ year but in $1^{\text {st }}$ year, the trend of increase of the fruit characters was found not pronounced. It might have been the cause of bearing habit and agro-climatic change. In second year, the highest number of female spikes (128), total fruits per tree (124), normal fruits (111), highest male to female ratio $(0.82)$, maximum fruit weight $(8.70 \mathrm{~kg})$ and fruit size $(35 \mathrm{~cm} \times 67 \mathrm{~cm})$ and lowest percent of deformed shape fruits (11\%) were recoded in $15 \mathrm{~g} \mathrm{~B}$ tree ${ }^{-1}$ which was significantly higher than other boron levels $\left(0-10 \mathrm{~g} \mathrm{~B}\right.$ tree $\left.{ }^{-1}\right)$. From two years study, the highest mean normal fruits $\left(93\right.$ tree $\left.^{-1}\right)$ and lowest percentage deformed shape fruits per tree (24\%) were also obtained by same boron level (15 g $B$ tree $^{-1}$ ). It is evident that boron contributed a significant role in pollination as well as fertilization during anthesis period. Generally the male spikes bloom earlier than the female spikes, boron stimulates the hormonal flow and increases the receptive capacity of the stigma for quick pollination and reduce the deformity of the fruits. Sankar and Singh (1965) and Jessy et al., (1996) reported that the number of fruits per tree is dependent on the number of female spikes and the ratio of male to female spikes.

Table 3a. Mean effect of boron and age of plants on the yield and yield contributing Characters of Jackfruit during the year 2002-2003 at Agricultural Research Station, Ramgarh, Khagrachari

\begin{tabular}{|c|c|c|c|c|c|c|c|c|c|c|}
\hline \multirow[t]{2}{*}{$\begin{array}{c}\text { Boron level } \\
\text { g tree }^{-1}\end{array}$} & \multirow{2}{*}{$\begin{array}{c}\text { Male } \\
\text { spikes } \\
\text { trees }^{-1}\end{array}$} & \multirow{2}{*}{$\begin{array}{c}\text { Female } \\
\text { spikes } \\
\text { tree }^{-1}\end{array}$} & \multirow{2}{*}{$\begin{array}{c}\text { Male } \\
\text { female } \\
\text { spike } \\
\text { ratio }^{-1}\end{array}$} & \multirow{2}{*}{$\begin{array}{l}\text { Total } \\
\text { fruits } \\
\text { tree }^{-1}\end{array}$} & \multirow{2}{*}{$\begin{array}{l}\text { Normal } \\
\text { fruits } \\
\text { tree }^{-1}\end{array}$} & \multicolumn{2}{|c|}{$\begin{array}{l}\text { Deformed fruits } \\
\text { tree }^{-1}\end{array}$} & \multirow{2}{*}{$\begin{array}{l}\text { Individual } \\
\text { fruit wt. } \\
(\mathrm{kg})\end{array}$} & \multicolumn{2}{|c|}{ Fruit size } \\
\hline & & & & & & No. & $\%$ & & $\begin{array}{l}\text { Length } \\
\text { (cm) }\end{array}$ & $\begin{array}{l}\text { Circumference } \\
\text { (cm) }\end{array}$ \\
\hline $\mathrm{B}_{0}$ & 95 & 29 & 0.31 & 22 & 6 & 16 & 73 & 3.90 & 23 & 46 \\
\hline $\mathrm{B}_{5}$ & 72 & 37 & 0.54 & 32 & 11 & 21 & 65 & 5.50 & 27 & 59 \\
\hline $\mathrm{B}_{10}$ & 66 & 69 & 1.04 & 65 & 35 & 30 & 46 & 6.40 & 29 & 52 \\
\hline $\mathrm{B}_{15}$ & 93 & 102 & 1.09 & 118 & 75 & 43 & 36 & 7.40 & 32 & 63 \\
\hline LSD (0.05) & NS & * & - & $\star$ & * & * & - & * & * & * \\
\hline \multicolumn{11}{|c|}{ Age of trees } \\
\hline 10 & 100 & 55 & 0.55 & 49 & 21 & 28 & 57 & 4.90 & 25 & 48 \\
\hline 15 & 76 & 54 & 0.63 & 50 & 22 & 28 & 56 & 6.00 & 26 & 61 \\
\hline 20 & 58 & 84 & 1.38 & 80 & 42 & 38 & 48 & 6.60 & 32 & 53 \\
\hline LSD (0.5) & NS & * & - & * & * & * & - & * & 46 & * \\
\hline
\end{tabular}

*= Indicates $5 \%$ level of significant; NS= Not Significant .

Table 3b. Mean effect of boron and age of plants on the yield and yield contributing Characters of Jackfruits during the year of 2003-2004 at Agricultural Research Station, Ramgarh, Khagrachari

\begin{tabular}{|c|c|c|c|c|c|c|c|c|c|c|}
\hline \multirow{2}{*}{$\begin{array}{l}\text { Boron } \\
\text { level g } \\
\text { tree }^{-1}\end{array}$} & \multirow{2}{*}{$\begin{array}{l}\text { Male } \\
\text { spikes } \\
\text { trees }^{-1}\end{array}$} & \multirow{2}{*}{$\begin{array}{c}\text { Female } \\
\text { spikes } \\
\text { tree }^{-1}\end{array}$} & \multirow{2}{*}{$\begin{array}{l}\text { Total } \\
\text { fruits } \\
\text { tree }\end{array}$} & \multirow{2}{*}{$\begin{array}{l}\text { Normal } \\
\text { fruits } \\
\text { tree }^{-1}\end{array}$} & \multirow{2}{*}{$\begin{array}{c}\text { Male } \\
\text { female } \\
\text { spike ratio }^{-1}\end{array}$} & \multicolumn{2}{|c|}{$\begin{array}{l}\text { Deformed } \\
\text { fruits tree }\end{array}$} & \multirow[t]{2}{*}{$\begin{array}{l}\text { Individual } \\
\text { fruit wt. }\end{array}$} & \multicolumn{2}{|c|}{ Fruit size $(\mathrm{cm})$} \\
\hline & & & & & & No & $\%$ & & Length & Circumference \\
\hline 0 & 90 & 29 & 26 & 7 & 0.32 & 19 & 73 & 4.0 & 26 & 50 \\
\hline 5 & 105 & 61 & 58 & 47 & 0.58 & 11 & 19 & 6.75 & 27 & 54 \\
\hline 10 & 134 & 95 & 91 & 80 & 0.71 & 11 & 12 & 7.64 & 32 & 58 \\
\hline 15 & 156 & 128 & 124 & 111 & 0.82 & 13 & 11 & 8.70 & 35 & 67 \\
\hline LSD (0.05) & * & $\star$ & * & * & * & * & - & * & * & * \\
\hline \multicolumn{11}{|c|}{ Age of trees } \\
\hline 10 & 101 & 58 & 55 & 43 & 0.58 & 12 & 22 & 5.47 & 27 & 42 \\
\hline 15 & 137 & 75 & 72 & 60 & 0.55 & 12 & 17 & 6.27 & 29 & 62 \\
\hline 20 & 125 & 101 & 95 & 82 & 0.81 & 13 & 14 & 8.36 & 34 & 68 \\
\hline LSD (0.5) & * & $\star$ & * & * & * & * & - & * & * & * \\
\hline
\end{tabular}


N. K. Halder et al.

\section{Effect of age of trees}

The mean effect of age of trees on the flower and fruit characters has been presented in Tables $3 a$ and $3 \mathrm{~b}$. It is evident that age group of trees significantly influenced on the studied parameters of jackfruits in both the years. It is also observed that as the increase of age of trees, number of male and female spikes, along with male to female ratio increased. Other fruit characters like total number of fruits, normal fruits per tree, fruit weight and fruits size also increased. The highest age group of trees (20 year trees) significantly dominated over all the fruit and flower characters in both the studied years (2002-2003 and 2003-2004). It is also found that the age group of trees showed dominant effect on the deformity of fruits. Highest number of female flowers (101), total number of fruits $\left(95\right.$ tree $\left.^{-1}\right)$, normal fruit number (82) and maximum fruit weight $(8.36 \mathrm{~kg})$ and fruit size $(34 \mathrm{~cm}$ $x 68 \mathrm{~cm}$ ) were recorded in 20 years old trees in $2^{\text {nd }}$ year. This was due to the significantly higher number of female spikes and increased male to female ratio (0.81). The percentage of deformed fruits dropped to $14 \%$ only while mean deformed fruits percentage was 21 (Table 4).

\section{CONCLUSION}

From two years study, it is evident that boron and age of trees exerted an encouraging effect on fruit characters of jackfruit. However, it can be summarized from this findings that 20 years trees with $15 \mathrm{~g} \mathrm{~B}$ tree ${ }^{-1}$ along with the blanket dose of N-P-K-S-Zn and CD @ 920:200:250:85:20 g/tree and $10 \mathrm{~kg}$ cowdung was optimum for increasing normal number of fruits and lowering the number of deformed fruits per tree. Considering the nutritional importance and epoch-making change in correcting the deformation of jackfruit, $15 \mathrm{~g} \mathrm{~B}_{\text {tree }}^{-1}$ for 20 years old trees along with the said blanket dose of fertilizers may be prescribed for boosting the jackfruit production in hill tract region of Bangladesh.

\section{LITERATURE CITED}

BBS, 2000. "Statistical Year Book of Bangladesh". Bureau of statistics, Statistics Division, Ministry of planning, Government of People's Republic of Bangladesh, p. 197.

Bose, T. K. 1990. "Fruits of India, Tropical and Subtropical". Department of Horticulture, Bidhan Chandra Krishi Viswavidyalaya, Kalyani. pp. 487-495.

Hayes, W. B. 1957. "Fruit Growing in India" (Third Edn.). Allahabad Kitabistan, Allahabad.

Hossain M. and A. Haque. 1997. Studies of the physical characteristics of jack fruit. Bangladesh Hort 5(1), 9-14.

Samaddar, H. N. and yadav, P. S. 1982. Flowering, floral biology, pollination, fruit set and fruit growth of jack fruit. Hort J 1, 54-60.

Sharma, M. R. 1964. "Morphological and Anatomical Investigations on Artocarpus Porst. IV. The Fruit Proc. "Indian Academy of Science, New Delhi. pp. 8, 60, 380, 393.

Tessy, J., Kumaran K. and Joseph, T. 1996a. Fruit set, fruit development and fruit drap in hard and soft flaked types of jack (Artocarpus heterophyllus L.). J Tropic Agric 31(1), 21-24.

Tessy, J., Kumaran K. and Joseph, T. 1996b. Flowering, floral biology and pollination in hard and soft flaked types of jack (Artocarpus heterophyllus L.). J Tropic Agric 31(1), 6-9. 